\title{
An empirical investigation of organizational memetic variation
}

\author{
Jill Shepherd • Bill McKelvey
}

Published online: 9 July 2009

(C) Springer Science+Business Media, LLC. 2009

\begin{abstract}
The potential of a theory based on organizational memes in coevolution with the environment has been postulated, but remains empirically under-developed. This study explores whether understanding organizational memetic variation is empirically possible and, if so, whether it might, with further development, provide managers with early indications of a misalignment between organizational action (operationalized as memetic variation) and strategic intent - the amount of memetic variation needed to stay aligned with the competitive environment. A method for empirically identifying knowledge-based memes in everyday practice is developed. It stems from modern advances in genetics allowing micro-level changes in genes to be linked to macro-environmental dynamics. Using the concept that memetic variation is caused by everyday, uncontrollable uncertainties of interpretation, memetic variation is reduced to seven categorical types. A highly exploratory quasi-experimental design allows a preliminary comparison of a would-be innovative 'Portfolio Management Committee' with self-organizing Internet chat-room settings that are representational of open-source innovation. Results are consistent with predictions showing that higher levels of variation are seen in the latter, despite the former's strategic intent of innovating to stay aligned with a dynamic environment. Further work is needed, however, to test reliability and validity.
\end{abstract}

\footnotetext{
J. Shepherd $(\varangle)$

Segal Graduate School of Business, Simon Fraser University, 515 W. Hastings St., Vancouver, BC V6B $5 \mathrm{~K} 3$, Canada

e-mail: jills@sfu.ca

B. McKelvey

UCLA Anderson School of Management, 110 Westwood Plaza, Los Angeles, CA 90095-1481, USA

e-mail: mckelvey@anderson.ucla.edu
} 
Keywords Memes - Variation - Environmental change - Organizational innovation · Knowledge $\cdot$ Open-source innovation $\cdot$ Empirical meme research

\section{JEL Classification $\quad \mathrm{O} 32 \cdot \mathrm{D} 21 \cdot \mathrm{M} 10$}

\section{Introduction}

Using the basic ideas of variation, selection, and retention, Darwin's evolutionary theory explained the diversification and survival of biological species. Advances in genetics, however, now allow researchers to link micro-level work on DNA, genes, and chromosomes to macro-level species evolution (International HapMap Consortium 2005). It is now generally accepted in biology that linking macro to micro analyses is what counts to create a more comprehensive theory of biological change.

Analogously, evolutionary theory has become pervasive in organization and management studies, aiming to explain the differentiation, survival, and growth of organizational populations (Aldrich and Ruef 2006). But in contrast to biology, organizational evolutionists are still adhering to Darwinian-analogous macro theory and have yet to link micro to macro. The trend towards the kind of empiricism that combines micro and macro evolutionary analyses into a single comprehensive perspective is not generally evident in organizational evolutionary analyses (McKelvey 1997; Lewin and Volberda 2003). Breaking new ground, however, Weeks and Galunic (2003) take an important first step in applying memetic theory to organizations- the theoretical emphasis on the importance of the 'selfish gene' in biology appears in their organizational application of the 'selfish meme' idea (Dawkins 1976). Significant problems remain, nonetheless. First, there is no meme-based empirical research of consequence. Second, as a result of genetic research, the most important empirical discoveries in biology are coming from the investigation of variation as much, if not more, than from the study of selection (Hinds et al. 2005; Myers et al. 2005). From this memetic perspective, organizations host populations of memes, variations among which affect evolutionary adaptation to changing environmental and/or competitive circumstances.

Third, the focus on micro variation is surely as important as in organizational than biological research because the rate of change is faster in organizations (except, perhaps, for viruses and bacteria (Marra et al. 2003). It is ironic, if not dysfunctional, that the organizational gene equivalent was initially chosen as the 'routine' because it changed slowly (Nelson and Winter 1982; Augier and Winter 2005). Based on Shepherd's dissertation (2002), the research reported here develops the first empirical analysis of variation in organizational memes. It is one of only three empirical studies specifically designed for relevance to formal organizations (the others being Lord and Price 2001; Vos and Kelleher 2001). Voelpel et al. (2005) develop a framework for analyzing innovation memes with empirical potential. It looks at how memes might become more or less shaped to align with organizational strategy.

Most memetic discourse is theoretical. In contrast, we present research that is emphatically empirical. We develop a method of identifying memes and how they vary in organizations. In a very preliminary manner, we use the method to assess 
whether it might be useful. Our work uncompromisingly follows well-known methods for achieving reliability and validity in micro-behavioral and text-based research. Reliability is assured by the use of an independent second coder and multiple settings. Validity is assured by using the quasi-experimental method (Campbell and Stanley 1963). Ours is the first empirical study of how memetic variation connects micro to macro evolution in a way analogous to modern genetics. Though we cannot stipulate its immediate managerial applicability, it does pave the way for justifying the worth of further more extensive work.

Our paper starts with basic theory: Memetic theory is introduced in Sect.2, and a summarized account of the potential of a meme-based cultural theory of the firm is given, with emphasis on empirical challenges. Within this section, the issue of the importance of fast-paced variation and studying variation in addition to selection is discussed. We discuss a variety of empirical challenges in our Methods section (Sect. 3). The Results, in Sect. 4, show the possible meaning of the patterns of variation creation evident in the data. Finally, in Sect.5, we discuss our contribution, limitations, and the future of memetic theory in organization science.

\section{Memetic theory applied to management}

In this section we present basic memetic theory for use in organizations. We argue the futility of depending on selection processes if variation does not exist, using Intel as a telling example. The section finishes with some key questions on memetics that drive us forward. Within the Method section, we then develop a way of identifying memes and categorizing them to understand organizational memetic variation. The method is applied to two settings producing a Results section to investigate its practicality and whether it should be rejected outright given various difficulties in its execution.

\subsection{Basic memetic theory}

Many authors have introduced macro evolutionary theory into the study of social systems or organizations (Campbell 1960; Aldrich 1979; McKelvey 1982; Nelson and Winter 1982). There are also a few others who have applied the 'selfish gene' micro evolutionary approach to cultural evolution (Heyes and Plotkin 1989; Gabora 1997; Speel 1999; Blute 2005) and organizations (Shepherd 2002). Weeks and Galunic (2003) draw from Dawkins 'selfish gene' and 'meme' extension (Dawkins 1976, 1982) to propose that a memetic cultural theory of the firm that is particularly able to accommodate the reality that not all of what a firm does is to its advantage. They argue that their 'cultural theory of the firm' is better able to account for the joint interests of both the firm and its employee-members than are either transaction-cost theories of the firm (Williamson 1975) or more recent knowledge-based ones (Kogut and Zander 1992; Boisot 1998). These latter theories assume that firms exist because they are efficient, respectively, at transacting and/or applying knowledge.

For neoclassical economists, only 'rational' firms survive (Friedman 1953). Spencer (1987) emphasized 'survival of the fittest'. Lewontin (1978) emphasized a more accurate phrase, 'survival of the tolerably fit'. In reality, to survive, a firm only needs to 
be fitter-more rational - than its competitors. To improve its collective rationality, a firm needs to know where its rationality-producing micro processes have broken down. A memetic theory of the firm highlights the likelihood that the intentions of all employees may not add up to something maximizing value, because such intentions are not controllable at an everyday level; yet the 'everyday' transactions are what make up the whole. Memetic analysis can help locate where the breakdown occurs.

Weeks and Galunic (2003) define memes as modes of thought. This is incorrect and empirically problematic. Dawkins (1976), defines memes as the unit of cultural evolution-they '... propagate themselves in the meme pool by leaping from brain to brain via a process which ... can be called imitation' (p. 192, our emphasis). Durham, cited in Gabora (1997), defines a meme as 'any kind, amount, and configuration of information in culture that shows both variation and coherent transmission'-just as a gene is a configuration of information in organic life that shows both variation and coherent transmission from body to body (Sect.2.1). 'Imitation' is a key component of the definition (Blackmore 1998).

We follow Durham (1991) and Dennett (2006) in defining memes as independent knowledge-based units of meaning that can be (socially) exchanged-transmittedwith more or less accurate transfer with or without alteration of meaning. We agree with Boisot and Li (2006) that the more organization-oriented sector of economics needs to look to biology for its models.

Our definition of memes is not acceptable to all, just as biologists also are not totally consistent in their definition of genes (Fox and Harel 2007). Our premise in this paper is that empirical work with meme definitions such as ours will, nevertheless, help to make our definition more robust and will move the current rather stale debate forward in what might prove to be a useful approach in the future.

\subsection{Variation before selection \& rapid variation}

Central to evolutionary memetics is the notion that evolution is blind variation with selective retention (Campbell 1960). It is the micro gene or meme that varies and benefits from being retained (Dawkins 1976). The self-organizing power of the system, so uncontrollable by any single element of it, is what makes it sustainable. Memes vary toward positive or negative adaptive advantage via mutation or by creative recombination (akin to crossover of different combinations of the double helix DNA base-pairs via mating in biology) (Blackmore 2000). To use Dennett's terminology, genetic variation is created via mutation through physical miscopying ('typos') and memetic variation through semantic miscopying ('thinkos') (Dennett 2006). ${ }^{1}$ Both produce differences in how the gene/meme relates to its organism/organization.

Memes, like genes, vary and are selectively retained. People do not have full control over how their memes vary, and hence what new knowledge they create, change, and transmit, nor which of these transmitted memes are retained in whose mind. Memes differ from genes in that they vary relatively quickly during social interaction. Burg-

\footnotetext{
1 Actual changes in a gene are by mutation. Crossover via mating changes combinations of genes in a particular offspring; individual genes remain unchanged.
} 
elman's studies of Intel $(1983,1991,2002)$ show the explanatory power of linking micro and macro analyses to understand organizational dynamics over time in changing environments. Early on, Intel's sustainability was at risk because internal selection pressures failed to mirror rapidly changing external selection pressures. Later, as its competitive environment came to change even more rapidly, Intel's struggle became even more problematic. More recently firms are giving up trying to adapt their own internal selection pressures to the changing external environment; instead, they are exposing variation in the form of innovative products and services directly to external pressures in what has become known as open source innovation (Business Week 2006a). Since selection can operate only if variation is created, organizations are now developing broader, often virtual, networks that create innovation through more variation (Business Week 2006b).

Burgelman's $(1991,2002)$ internal ecology model takes a dynamic view of strategizing generated in high-tech Intel. Strategic initiatives in firms emerge in patterned ways. Variation occurs as individuals (re)interpret these initiatives. Whatever variation is produced is subject to both internal and external selection pressures. There are times and contexts when variation needs to be encouraged and selected for (e.g., when the environment is rich with opportunity and uncertainty) and times when it should be avoided and selected against (e.g., when the environment is unchanging or a topdown strategy needs to be rapidly implemented during a crisis) (Burgelman 2002). He sees managing variation, production and selective-retention pressures as enabling managers to align deliberate strategic intent with organizational action. Equally, the idea that organizations coevolve with their environment-with the result that neither are unchanging-is empirically under-investigated (McKelvey 1997; Lewin and Volberda 2003). Others have explored how variation production alters according to the task at hand-for example, the reinterpretation of policies written to deal with risky circumstances involving employee safety is unwise (Rosness 2004)—whereas idea brokers who bridge functional and meaning silos to create new knowledge produce constructive variation (Burt 2005) relevant to high-velocity environments (Brown and Eisenhardt 1997). Similarly, internal organizational variation is productive when a new entrant destabilizes the niche, thereby changing industry rules and boundaries (Sampler 1998).

Our empirical memetic research differs from Burgelman's in six ways, however, because of our emphasis on the blind variation-selection-retention process unfolding at a micro level (Campbell 1960); our research makes fewer assumptions about intentionality. Furthermore, our research:

1. Emphasizes the interpretive dynamics by which variation is created, whereas Burgelman's work emphasizes the selection pressures acting after variation has been created. The selection-retention process can only act on what variation is actually present. If there is not enough, the selection pressures become irrelevant. This makes the process of variation production crucial.

2. Studies a shorter time frame of minutes and hours, whereas Burgelman's work takes place over a longer time frame of years and epochs of CEOs. Working with a shorter time-frame increases the potential utility of the variation concept, as the 
earlier that insufficient variety creation can be discovered the more reactive, and perhaps even proactive, a company can be to changes in the environment.

3. Includes all variations - intentional or unplanned - by individuals at all levels, not just intentional variation by top-level managers aimed at strategic initiatives or intentional variation by middle managers aimed at lower-level different strategic initiatives, for the reason that all variation contributes to the overall rate of variation creation relative to efficacious adaptation.

4. Presumes that the nature of intentionality within an organization cannot be assumed. There may or may not be an overall intentionality throughout the organization aimed at the macro strategic-intent level. There may or may not be, at a micro-level, coherence supporting a particular macro-level intentionality.

5. Assumes that whereas the micro everyday production of variation is not manageable, it is possible to discern variation patterns as or after they have occurred and then decide whether these emergent 'weeds' (Mintzberg and McHugh 1985) support top-level objectives.

6. Provides sufficient data for patterns in variation creation to be identified with confidence, even though the time period over which data collection takes place is short.

Memetically the driving questions for us are:

1. What is a meme? This despite the various definitions above. Memes ought to be 'analytically divisible' (Weeks and Galunic 2003, p. 1322) but what this might mean in practice is another matter. How can a concept as abstract and subjective as a 'configuration of information' be identified in real data?

2. How can such data be analyzed to reveal different variation-creation dynamics preceding the effect of different selection-retention forces? Given that the former is the focus of this research-can a way of working empirically with the microlevel process that produces memetic evolution be developed that distinguishes the different types of 'thinkos' representative of alterations and/or the creative results of recombination and which, then, determine the rates and types of variation?

3. What is the basis of reliability, validity, and confidence in results? How many memes need to be identified and analyzed, and with what level of accuracy, to be certain that any pattern of variation creation can be considered reliable enough for insights and managerial implications to be drawn from the research?

4. How and when do micro events become determinants of macro outcomes?

This paper principally covers the first two of these driving questions, whilst \#3 is explored to some degree, and the remainder to a very limited degree.

\subsection{A first empirical test of practicality}

In principle, then, a memetic theory of the firm seems useful, but there are difficulties. Recently, it has fallen on hard times because of definitional ambiguity (Gatherer 1998; Rose 1998; Lissack 2004). This has made an already daunting empirical challenge even more illusive. And yet, without empirical inquiry its utility remains unknown. Early research in genetics, specifically, was typified by: 
1. Laborious genetic sequencing methods, which have since been largely automated;

2. Lack of ability to identify genes in absolute terms, which is still very much the current situation; and

3. A dream that micro-level research would yield insights, which at long last, has proven to be the case.

The method we describe below is no different. It is very laborious and far from automated; it involves field and office work; it requires much operational definition and tedious coding processes. It is at the beginning, where genetics was before the double helix was discovered (Watson and Crick 1953).

In light of this, our paper_-based on Shepherd's dissertation (2002)—-takes on special meaning because it is one of very few empirical studies of memetics in general, and only one of three empirical studies of memetic evolution pertaining to organizations - the other two are by Lord and Price (2001) and Vos and Kelleher (2001). Shepherd's research is the first and only attempt to date at operationalizing memes and empirically studying them in a managerial setting. She investigates whether an understanding of meme dynamics can be developed which, if verified by further work, might help managers understand the performance implications of the (memetic) culture of their organization. More specifically, this research attempts to make the first preliminary step in investigating whether a memetic research method might be able to access and explain levels of organizational variation.

\section{Method development}

This section details how the research addresses the methodological challenges associated with making the proposed theory work in practice. First, the nature of the data collected is justified. How memes are identified follows. The analytical step of defining when and how memes vary is described. Then, the validity of the method is put to a test in an exercise of inter-coder reliability. The empirical memetics developed here is also compared with progress in genetics as to what aspects of its methods matter most.

\subsection{Data collection}

As regards the form of data suitable for the identification of memes, everyday conversations need to be collected verbatim in a context understandable by the researcher. The former ensures that hindsight is not obscuring the real process of cultural evolution. The latter makes it possible for the researcher to understand the meaning of the discourse through careful deliberation, thereby avoiding reinterpretation of the data. There is, however, an intrinsic problem in that the concept of memetic evolution is reliant on the uncertainties of interpretation-no one can be sure of knowing another person's mind perfectly. If this is so, then however familiar the researcher is with the context in which data collection is taking place, there is the danger of inadvertent reinterpretation of the data when deciding how to divide it into memes, thereby resulting in researcher thinkos. Highly contrasting settings are chosen to increase the likelihood 
that comparison between them will reveal differences. 'Contrasting' in this research has two dimensions; low/high variation rates and styles of managing that might affect the variation rates.

\subsubsection{Internet variation-control setting}

Whereas in most experiments the 'control group' is expected to remain unchanged absent the treatment effect, 'control' here is the opposite. We had to find a setting that would indicate that memetic analysis would, indeed, show variation if it existed. Without this we have no means of checking whether 'no variation' in the experimental context - the firm - is because the method does not pick up memetic variation or whether the firm, in fact, has no innovation, as indicated by its lack of memetic variation.

Internet chat rooms were chosen as the high variation 'control' group. Elements assuring variation are:

- Internet chat room rules, referred to as Netiquette, deter people from repeating the same material for promotional gain.

- Virtuality produces uncertainty and attracts a diverse set of people.

- Style of managing is self-organized with no higher authority other than Netiquette affecting the discussion.

This choice of Internet chat rooms is further justified by organizations with a focus on innovation beginning to use Intranets and Extranets in the areas of innovation and company-wide strategizing because they produce large amounts of variation. The Internet setting therefore acts as a high variation 'control' to the managerial setting.

Within each setting, data are collected within three mini-cases, allowing for withinsetting comparison as well as between-setting comparison; presuming that the method can pick up more subtle differences in variation creation. These mini-cases were chosen to ensure the data-set includes contrasts and similarities so as to test the sensitivity of the method and produce a range of insights.

The Internet-variation control setting is composed of exchanges collected from three Internet chat rooms, hosted by the same ISP provider. Discussion is self-managed without hierarchy or authority. The subjects of the chat rooms include, first, 'Mars' - a chat between a few scientists about the failure of a mission to Mars. The Mars case, therefore, has some similarity to the firm, since both involve a relatively small group of scientists. The second chat is 'Religion' - in which religious people and atheists discuss the question of, Why fear God? This is chosen as a direct contrast to Mars because it involves more people with more diverse views around a less rational, empirically-based subject. Last is 'Gun Policy'-a debate between those pro- and anti-gun policy, chosen because it contains a breach in Netiquette in that one person repeatedly posts information about a petition, which is against Netiquette.

The cases generally represent increasing discursive complexity and social construction. Mars has a simple discussion structure involving supposed 'facts' within 
a single community of scientists, in that they are discussing the failure of the mission to Mars in terms of the incorrect interpretation of scientific conversion units. Religion is a debate about what some might deem objective facts, that others deem subjective; it harbors two distinct communities. Gun Policy contains both objective and subjective facts within both sides of the debate and, over time, contains an alternative, higher-level debate about the concept of freedom. The cases contain increasingly complex mixtures of different types of knowledge, types of communities, as well as interactions between the knowledge and communities. All three contain enough diversity such that the method would be considered a failure if it did not show memetic variation.

\subsubsection{Management-test setting}

This is a 'test' experiment in that the 'test' is whether managers comprising the Portfolio Management Committee in a would-be innovative division of a recently privatized firm are, in fact, showing the memetic variation required to move in innovative new directions under what appear to be difficult 'groupthink' conditions (Janis 1972). The division is underperforming by any benchmarking standards 'measuring' it against commercial counterparts. Top management's impression following internal discussions and management consultant reports was that they were not innovative despite this being their raison d'etre.

There were six participants in each meeting; this did not vary, except in 'Off Agenda', chosen because of the unscheduled absence of the Managing Director (MD), and in 'Project', where a project leader joins the group. The meeting typically took place over a single day and followed the same formal format. The six people included the MD, the Chief Scientific Officer, the Chief Marketing Officer, a representative from the broader company, the Committee secretary and the Financial Director. Indeed, because of this fear of a lack of innovation one Committee member was championing a move to a process where new development ideas (new projects) were discussed at either 'town meetings', to which the whole company and selected suppliers and customers were invited, or if this proved too unmanageable, a move to an intranet 'innovation jam' style chat room. Attendees/participants would also be asked their view on the new process. This proposed change would be in stark contrast to the current scenario where the Committee alone decided on which development projects to finance and whether the process should be changed. The champion viewed this research as helping them decide whether to make this transition, against a background of a substantial degree of resistance amongst some more established members of the Committee.

Fisher (1930) stated that: 'The rate of evolution of a character at any time is proportional to its additive genetic variance at that time' (quoted in Depew and Weber 1995 , p. 251). For the firm to survive in its macro evolutionary niche, it has to acquire a comparable internal rate of variation. Ashby's (1956) Law of Requisite Variety also holds that internal variety has to match external variety. Consequently, to be competitive in its niche (competitive context) the firm should exhibit a high rate of internal variation. 
Several key elements combine to suggest that the firm's variation rate is not very high:

- The style of managing is top-down hierarchical.

- A close-knit team of senior managers works within the very formal Portfolio Management Committee.

- All managers have worked for the company for many years and all have a strong technological/scientific background.

- There is little heterogeneity in the form of new members on the Committee.

- The company had previously been a government organization.

All the elements of groupthink are present.

The management setting contains three discussions within the Portfolio Management Committee meeting typical of the many other discussions the researcher attended. Each of these offers a test of whether the managers are able to escape groupthink and show the memetic variation necessary to move the firm in innovative directions. 'Project' captures dialogue between the managers and a project manager as a new idea is presented in the quest for resources. This is chosen because it involves an exchange of information between the senior management group and a project manager and is very much part of the standard committee approach to innovation. The 'Internal' case is a discussion about changing internal processes and routines to boost innovation as determined by the pre-set agenda. This is chosen because, unlike the first case, it is by design supposed to be directly innovative. The pressure is to try and create internal processes more able to promote innovation, as the managers wish to go for an IPO, but cannot until they are more innovative. The third case, 'Off Agenda', captures a period of time when the most senior manager, the Managing Director unexpectedly leaves the meeting room. The discussion includes complaints about workload, specifically details of a project not on the agenda but brought into the discussion following a comment about a large pile of papers on the table in front of a manager pertaining to this project. This is chosen because it represents a chance to assess whether the MD's presence or absence changes the memetic-variation rate in the meeting.

The choice of cases produces some overlap between the settings. The Gun Policy case contains spam as someone tries to promote their pro-gun views by repeatedly posting the same exchange, which points people towards a web-site promoting guns and probably reducing variation creation by simulating the following of an agenda. Presumably, therefore, one might expect the Gun case to be somewhat similar to the organizational setting in that spamming in the Gun case reduces variety creation. The Mars case involves a smaller group of people than the other two chat-rooms and a closer-knit one in that it is composed of scientists and a scientific journalist, making it more or less akin to the management setting. Therefore, one might expect the Mars case to exhibit evolution more like the Portfolio Management Committee if small group size and subject area has an effect on variation. The Project case involves the intention of sharing understanding between senior managers and project managers with a view to dedicating further resource to the project's development. The Internal case does explicitly involve thinking of new ideas but does not explicitly embrace brainstorming rules. The Off Agenda case has no agenda and a slightly differing set of people (when the MD leaves the room). Further, Internal and Off Agenda might be 
more like the control setting, as in the former case it is intended to promote variation and the latter case is not constrained by a managerial agenda or the presence of the most senior manager.

Since we are at the beginning of empirical memetic research, it is worth commenting on some method aspects that might be easily criticized. First, the management setting is not chosen assuming that it represents all interactions in the organization. It is chosen knowing that innovation is primarily controlled and reviewed at the Portfolio Management Committee meeting and because the organization is questioning whether this meeting is effective in its management of innovation. The comparison is, therefore, between the intentional aims of the meeting under consideration and the actual behavior as analyzed memetically. Second, whereas at the time, internet chat rooms were not seen as organizational, they can now be considered as an organizational context given the use of the Internet by organizations for innovation. The most established case is IBM global innovation jams (Bjelland and Wood 2008). Furthermore, with the advent of mash-ups and pipes (reusing other people's Internet content and filtering, refining, and recombining it in novel ways) within the semantic web, that in time might well become organizational contexts, the social Internet is a context worthy of study of relevance to organizations.

\subsection{Identifying memes}

If memes are considered as discrete packages of knowledge (Gabora 1997; Dennett 2006), then they must have stand-alone meaning. They must mean something to the people amongst whom they are being exchanged. So, a person present within a specific context, or familiar with this context, would understand the meaning of the meme, whereas any fewer words would carry no meaning. This concept stems from gene identification. One way geneticists identify genes is by removing codons (where codons have a discrete role in themselves equivalent to words) of what they suspect to be a gene or fusing different pieces of genes until what they have left no longer expresses a specific function (Martzen et al. 1999).

The same approach is used here within memetics. What is expressed in a conversation by someone is viewed and words (equivalent to codons) are eliminated. Each time it is questioned as to whether the semantic value of the expression remains intact. Another word for meme when defined this way is morpheme, defined as the smallest linguistic unit that has semantic meaning. Morphemological analysis is used in Japanese and Chinese to segment a given sentence into a row of morphemes. Do the words still have some stand-alone meaning within the context in which they are expressed? What is the smallest set of words within a discourse that holds a meaningful statement about the world? It is a matter of minimizing interpretive freedom: (1) 'Clever' applies to many things and meanings; (2) More words, like 'clever at algebra' narrows it; (3) still more words broadens it, as in 'clever at math and other analytical methods'. Synonyms, because they do share the same meaning, are considered as identical when identifying memes, unless in the context under study one synonym might be more likely to be misunderstood than another. 
In sociology, the established equivalent and very similar method is found in content analysis (Krippendorff 1980). However, while it is a form of content analysis via word counts, and though it does consider context, it differs because it does not search for meaning within specific small-word clusters. For example, in memetics the same word can mean something very different in different contexts. Equally, the phrase, 'yes I agree' has an infinite number of possible meanings according to what the person agrees with. It is, however, a form of memetic evolution in that no reinterpretation has taken place between people. Instead, to use Durham's phrase, 'coherent transmission' (quoted in Gabora 1997, Sect. 2.1) has taken place.

Painstaking micro-level research is considered important in genetics as small changes can create big effects and it is assumed this is the case in memetics. For example, semantic indexing was rejected as a possible automating tool because it is not as subtle as the human mind. ${ }^{2}$ It would have speeded up the method and in time might become equivalent to the automated ways of identifying genes now existing.

Identifying memes is not perfect, but then neither is it in genetics despite that field's far greater acceptance as a method. In memetics, issues include personal (researcher) interpretation, Machiavellian contributions where a person says something they do not mean or people who later, in another context, alter their contribution upon reflection. Inter-coder reliability testing conducted here (see later section) deals with the former. The latter two cannot be dealt with perfectly, other than to say that decisions are taken in the meeting on the basis of the exchanges in the meeting; therefore they are real in this sense.

Equally there is the issue of how long-lived a meme needs to survive for it to be a genuine variant. Here we consider any variant, however short lived, as a meme in that it has the chance, however remote, to become longer-lived by being replicated by another person. Another definition could be that it needs to last until it can be implemented to create (or not) organizational value, but this would be a definition that would prohibit us from achieving our aims of looking at innovative potential. We strive to demonstrate how memes can be operationalized and how micro and fast paced variation occurs in organizations.

Table 1 summarizes the main differences between memes and genes. Blackmore (1998) asserts that memes evolved because they allow for variation within generations of genetic variation and compete with the faster forms of genetic variation (such as viruses and bacteria). Their copy-fidelity, therefore, is generally lower and they survive for less time.

Table 2 highlights what an organizational meme can be, both in general terms using the PC company Dell, as well as the company studied in this paper, and in terms of their variation rates in addition to transmission fidelity and fidelity. Thus, routines are organizational memes that rarely change, but can become unfit if not changed when

\footnotetext{
2 Suppose people say the following: 'Your attitude is bad'. 'Your attitude sucks'. Your attitude is terrible'. 'Your attitude is dreadful'. 'Your attitude is awful'. 'Your attitude stinks'. 'Your attitude disgusts me'. In a conversation about specific recent review article people could easily attach the same meaning to the terms in italics, though the last two begin to take the interpretive tone in a different direction. For this sort of word usage we think human interpretation is more valid than computer methods.
} 
Table 1 Gene-meme differences

\begin{tabular}{|c|c|c|c|}
\hline Characteristic & Memes & Genes & Comment \\
\hline $\begin{array}{l}\text { Structure-knowledge } \\
\text { relationship }\end{array}$ & $\begin{array}{l}\text { Semantic meaning has } \\
\text { to be discerned within } \\
\text { context of the } \\
\text { expression of meme }\end{array}$ & $\begin{array}{l}\text { Physicality of gene } \\
\text { needs to be expressed } \\
\text { in terms of a } \\
\text { biological function }\end{array}$ & $\begin{array}{l}\text { Both have to be } \\
\text { interpreted to discern } \\
\text { functionality }\end{array}$ \\
\hline Transmission Fidelity & Generally low & Generally high & $\begin{array}{l}\text { There would be little } \\
\text { point in memes (i.e. } \\
\text { they would not have } \\
\text { evolved) unless they } \\
\text { varied on average } \\
\text { more than genes. In } \\
\text { gene-meme } \\
\text { co-evolution at its } \\
\text { fastest [e.g., vaccines } \\
\text { and viruses (Burke } \\
\text { 1997)], genes and } \\
\text { memes fight to vary } \\
\text { more quickly }\end{array}$ \\
\hline Fecundity & Generally low & Generally high & $\begin{array}{l}\text { Equally, if memes } \\
\text { lasted on average as } \\
\text { long as genes they } \\
\text { would evolve at the } \\
\text { same slow rate as in } \\
\text { biology, which would } \\
\text { confer no } \\
\text { advantageous } \\
\text { evolutionary role on } \\
\text { them }\end{array}$ \\
\hline Fitness & Is it copied? & Is it copied? & $\begin{array}{l}\text { In both cases copying } \\
\text { can have negative } \\
\text { effects on fitness but } \\
\text { on the whole will be } \\
\text { positive when } \\
\text { fecundity is high }\end{array}$ \\
\hline
\end{tabular}

needed. Ideas emanating from open source innovation websites harbor most variants, are unlikely to be transmitted in an unchanged fashion, and survival means they have been internalized within the organization as a strategic idea and sometimes eventually as a routine.

Details about the amount of data appear in Table 3, which shows that each exchange between one person and another within the discourse contains a range of between 1.1 and 2.7 independent and transferable packages of meaning, i.e. memes. In total, some 683 memes within 335 exchanges are analyzed in the Internet-control data-set and 726 memes within 501 exchanges in the management-test data-set. Transcripts of all of the source data are available; they show the conversion to the memetic data sets of each case. Transcripts are exact and therefore include emoticons such as ':)' that have meaning in the modern day of PCs.

What is and what is not a meme is a vital question. In the following example from the data collected we see that in the first meme some words could be eliminated (the 
Table 2 Types of organizational meme

\begin{tabular}{|c|c|c|c|c|}
\hline $\begin{array}{l}\text { Organizational } \\
\text { typology }\end{array}$ & $\begin{array}{l}\text { Dell's Memes } \\
\text { (from website } \\
\text { 12/Dec/07) }\end{array}$ & $\begin{array}{l}\text { Business Unit } \\
\text { containing } \\
\text { the PMC }\end{array}$ & $\begin{array}{l}\text { Variation/transmission } \\
\text { Fidelity }\end{array}$ & $\begin{array}{l}\text { Fecundity/ } \\
\text { Fitness }\end{array}$ \\
\hline Routine & $\begin{array}{l}\text { How to serve } \\
\text { online orders } \\
\text { written into a } \\
\text { policy document } \\
\text { on an internal } \\
\text { knowledge data } \\
\text { base }\end{array}$ & $\begin{array}{l}\text { The monthly PMC } \\
\text { or the } \\
\text { Stage Gate process } \\
\text { operating within } \\
\text { the committee }\end{array}$ & $\begin{array}{l}\text { Low variation. } \\
\text { Transmitted with } \\
\text { high fidelity }\end{array}$ & $\begin{array}{l}\text { High fecundity. } \\
\text { Fitness good, } \\
\text { unless routine is } \\
\text { not being varied } \\
\text { because } \\
\text { organization is } \\
\text { stuck in a } \\
\text { cultural stasis } \\
\text { whereby need to } \\
\text { change routine } \\
\text { not questioned }\end{array}$ \\
\hline Template & $\begin{array}{l}\text { Online order } \\
\text { process as filled } \\
\text { in by customer } \\
\text { online on Dell } \\
\text { employee within } \\
\text { call centre }\end{array}$ & $\begin{array}{l}\text { The template of } \\
\text { the minutes of } \\
\text { the PMC }\end{array}$ & $\begin{array}{l}\text { Low variation. } \\
\text { Transmitted } \\
\text { with high } \\
\text { fidelity }\end{array}$ & $\begin{array}{l}\text { High fecundity } \\
\text { Fitness good } \\
\text { unless routine } \\
\text { not being varied } \\
\text { as organization } \\
\text { stuck in a } \\
\text { cultural stasis } \\
\text { whereby the } \\
\text { need to change } \\
\text { template not } \\
\text { questioned }\end{array}$ \\
\hline $\begin{array}{l}\text { Mission statement } \\
\text { or organizational } \\
\text { vision }\end{array}$ & $\begin{array}{l}\text { 'Dell's mission is } \\
\text { to be the most } \\
\text { successful } \\
\text { computer } \\
\text { company in the } \\
\text { world at } \\
\text { delivering the } \\
\text { best customer } \\
\text { experience in } \\
\text { markets we } \\
\text { serve' }\end{array}$ & $\begin{array}{l}\text { Cannot be given } \\
\text { verbatim for } \\
\text { confidentiality } \\
\text { but involved } \\
\text { 'becoming } \\
\text { highly } \\
\text { innovative in a } \\
\text { commercial } \\
\text { sense' }\end{array}$ & $\begin{array}{l}\text { Aim would be for } \\
\text { low variation and } \\
\text { high fidelity but } \\
\text { this would need } \\
\text { to be tested and } \\
\text { would not be the } \\
\text { case with a new } \\
\text { mission or vi- } \\
\text { sion. } \\
\text { Dell's mission has } \\
\text { remained } \\
\text { relatively constant } \\
\text { The mission of the } \\
\text { Business Unit } \\
\text { under study } \\
\text { changed just prior } \\
\text { to data collection } \\
\text { and varied } \\
\text { according to } \\
\text { managerial } \\
\text { interpretation }\end{array}$ & $\begin{array}{l}\text { Would want low } \\
\text { fecundity to } \\
\text { bring high } \\
\text { fitness but need } \\
\text { to review } \\
\text { periodically for } \\
\text { either unfit low } \\
\text { transmission } \\
\text { fidelity or signs } \\
\text { that high } \\
\text { variation means } \\
\text { senior } \\
\text { management are } \\
\text { not changing the } \\
\text { mission/vision } \\
\text { as they should }\end{array}$ \\
\hline
\end{tabular}

last six), and yet the meaning would stay the same, albeit without as much strength. Despite this, to state that these six words are a meme in their own right makes no sense, as they are have no semantic independence. The 'following meme' we show has no sense unless it is viewed in the context and expressed meaning of the preceding meme. 
Table 2 continued

\begin{tabular}{|c|c|c|c|c|}
\hline $\begin{array}{l}\text { Organizational } \\
\text { typology }\end{array}$ & $\begin{array}{l}\text { Dell's Memes } \\
\text { (from website } \\
\text { 12/Dec/07) }\end{array}$ & $\begin{array}{l}\text { Business Unit } \\
\text { containing } \\
\text { the PMC }\end{array}$ & $\begin{array}{l}\text { Variation/transmission } \\
\text { Fidelity }\end{array}$ & $\begin{array}{l}\text { Fecundity/ } \\
\text { Fitness }\end{array}$ \\
\hline $\begin{array}{l}\text { Unit of knowledge } \\
\text { on knowledge } \\
\text { data base }\end{array}$ & $\begin{array}{l}\text { How to fulfil a } \\
\text { routine order or } \\
\text { How to collate } \\
\text { customers' } \\
\text { suggestions } \\
\text { gleaned from a } \\
\text { call centre }\end{array}$ & $\begin{array}{l}\text { Routine on how to } \\
\text { present a new } \\
\text { project to the } \\
\text { PMC Ideas from } \\
\text { internal intranet } \\
\text { on how to fulfil a } \\
\text { new customers' } \\
\text { needs }\end{array}$ & $\begin{array}{l}\text { Would depend on } \\
\text { unit of } \\
\text { knowledge as to } \\
\text { how variable it } \\
\text { is-whether it is } \\
\text { a piece of static } \\
\text { knowledge or } \\
\text { part of a chat } \\
\text { room within the } \\
\text { knowledge data } \\
\text { base where } \\
\text { employees are } \\
\text { commenting on } \\
\text { a suggestion to } \\
\text { change a routine } \\
\text { or policy }\end{array}$ & $\begin{array}{l}\text { Again would } \\
\text { depend both on } \\
\text { whether } \\
\text { knowledge } \\
\text { brought fitness } \\
\text { and whether } \\
\text { organization } \\
\text { was geared } \\
\text { towards fitness } \\
\text { by examining } \\
\text { variants as } \\
\text { potential sources } \\
\text { of fitness }\end{array}$ \\
\hline Strategic idea & $\begin{array}{l}\text { To alter the } \\
\text { ordering process } \\
\text { to serve a new } \\
\text { idea from a } \\
\text { customer (see } \\
\text { open source idea } \\
\text { below) }\end{array}$ & $\begin{array}{l}\text { To alter the Stage } \\
\text { Gate Process } \\
\text { and PMC } \\
\text { structure }\end{array}$ & $\begin{array}{l}\text { Reasonable varia- } \\
\text { tion. } \\
\text { Transmitted with } \\
\text { some fidelity }\end{array}$ & $\begin{array}{l}\text { Would hope that } \\
\text { enough variants } \\
\text { would exist for } \\
\text { some to have } \\
\text { low fecundity } \\
\text { and become new } \\
\text { routines or units } \\
\text { of organizational } \\
\text { knowledge }\end{array}$ \\
\hline $\begin{array}{l}\text { Idea on an open } \\
\text { source } \\
\text { innovation site }\end{array}$ & $\begin{array}{l}\text { 'Some of us } \\
\text { would like the } \\
\text { configuration } \\
\text { option of being } \\
\text { able to get a } \\
\text { computer with } \\
\text { no operating } \\
\text { system } \\
\text { installed'. www. } \\
\text { ideastorm.com }\end{array}$ & Not relevant & $\begin{array}{l}\text { Highly variable; } \\
\text { low fidelity; } \\
\text { until taken into } \\
\text { organization to } \\
\text { become a strategic } \\
\text { idea }\end{array}$ & $\begin{array}{l}\text { As per strategic } \\
\text { idea but even } \\
\text { higher number } \\
\text { of variants with } \\
\text { lower fecundity }\end{array}$ \\
\hline
\end{tabular}

* Portfolio Management Committee

Table 3 Memes per exchange per case

\begin{tabular}{lllllll}
\hline & Mars & Religion & Gun & Project & Internal & Off Agenda \\
\hline Number of memes & 281 & 158 & 244 & 373 & 255 & 98 \\
Number of exchanges & 103 & 109 & 123 & 260 & 158 & 83 \\
Average memes per exchange & 2.7 & 1.4 & 2 & 1.4 & 1.6 & 1.1 \\
\hline
\end{tabular}

\section{Meme:}

Because it seemed to me that they had the conditions wrong, the material wrong ... everything wrong. 
Following meme:

It was terrible.

To use another example from the organizational setting:

Meme 1:

Yes I think it's important that as David says that some of our key people are being listened to and they have a chance to ... there is some enthusiasm out there to do something with.

Meme 2:

Obviously we have got to set some boundaries otherwise we will just spend every single day just talking about ideas and not doing anything but I think it will have an impact.

Meme 3:

To be honest I do not care if after the first couple it goes stale because in two of those meetings one idea could come out, one thing could come from one of those things.

It can be argued that in all of these cases, two memes exist within the one coded as follows:

Meme 1:

Yes I think it's important that as David says that some of our key people are being listened to and they have a chance to ....

Meme 2:

... there is some enthusiasm out there to do something with.

Meme 3:

Obviously we have got to set some boundaries otherwise we will just spend every single day just talking about ideas and not doing anything.

Meme 4:

... but I think it will have an impact.

\section{Meme 5:}

To be honest I do not care if after the first couple it goes stale.

Meme 6:

... because in two of those meetings one idea could come out, one thing could come from one of those things.

It can be argued, however, that in each of the foregoing cases the meaning of the memes is connected so tightly that their meaning is heavily diluted unless they are considered as one meme.

So two rules ensue:

1. Context matters.

2. Comprehensive meaning matters.

This approach was confirmed when it came to second coding, more details of which follow. The identification of memes in exact terms does remain an obstacle to reliability.

\subsection{Defining when and how memes vary}

Having sourced comparative data in a form that can be manipulated into data-sets made up of consecutive memes, the task of analyzing it faces the researcher. The memetic 
framework (Durham 1991; Blackmore 2000) states that each time a meme is expressed it can either be ignored or dropped, explicitly retained unchanged, or reinterpreted in some way, just as a gene might not be retained in the subsequent population, or might be retained intact, or changed in some way.

Specific inspiration for Shepherd's analytical method comes from genetics. Genes can change to the point they no longer function in a way that even remotely resembles the function they had previously. Such mutations occur when the DNA is either damaged or changed in a way that alters the message carried by that gene. Single 'point mutations' can cause the death of a gene because the information it harbors is lost. Others can cause new messages to be created that enhance the chances of the gene being retained if it confers advantage. Categories of genetic mutations have been established. Gene inversions alter the order of genes on a chromosome. Gene translocations transport genes onto other chromosomes. Gene insertions and deletions occur. An appropriate analytical approach, therefore, is to determine whether analogous categories can be created that identify the amount of variation lost or created at each opportunity within memetics. This categorization allows an understanding of how much variation is created, in what ways, and whether these dynamics are as intended by the practising managers.

Categories of variation are developed using grounded theory (Glaser 1992) such that no categories of variation are considered to exist a priori. To generate categories of variation, each meme is compared with its former meme form to discern what content has been lost or added in what way. By examining each exchange, the type of variation is categorized, creating a new category if one has not already been created, into which the exchange under scrutiny easily falls. In the case of no retention, memes are compared with those that follow to see whether they are lost or retained in any form in subsequent conversations, giving a measure of the overall diversity of the meme pool. Given the number of memes and their grounded nature, this exercise involves working intensely to know the data well, balancing creativity with rigor (Langley 1999). A repeat exercise will take much less time.

Taken as a whole, the data reveal seven different ways in which variation is (or is not) created (See Table 4). Examples of each category follow; they represent the range of settings discussed above. They:

- Involve one meme per exchange (posts in the internet setting or two people talking in the organizational setting) and are therefore easier to display than exchanges containing multiple memes;

- Do not reveal anything confidential in the organizational setting; and

- Do not need the context of previous memes to be understood by the reader not familiar with the context.

The examples show the case from which the memetic data are extracted, which memes are taken, the meme and the following meme in the discourse. Quoted memes are in italics. Given word count constraints, for each category only one example is given.

1st Category: In the exchanges categorized as 'repeats', memes found in the data are either exact or very near exact copies of previous memes. The relation between them is, therefore, one of perfect copying and no variation creation. 


\section{Organizational examples (Internal)}

In this case of an exchange categorized as a repeat, the Marketing Director confirms in the second exchange what the Managing Director states in the first.

Meme:

Because it seemed to me that they had the conditions wrong, the material wrong ... everything wrong.

Following meme:

It was terrible.

Arguably this meme pair is on the verge on being categorized as an emphasis, in that emotion is present in the second meme that is not in the first. This proves in reality we have a continuum rather than discrete categories but for the sake of analysis, as in a Likert scale, categories are used. In contrast in the Gun Policy case repeated posts in the form of spam represent definitive repeats.

2nd Category: In some cases memes are found in the data that are different from the previous ones in that they relate to the world in the same way but add more indepth detail about an aspect of the previous meme. Such exchanges are categorized as 'emphasis'. The relation between them is one of imperfect copying and variation creation which provides greater depth of meaning.

\section{Control example (Mars)}

Referring to conversion factors:

\section{Meme:}

Poundal pound foot. Pound slug foot. Pound snail inch.

Following meme:

Of course we are left with the contradiction that a snail is even more sluggish than a slug itself.

Here, there is obvious humor in adding a fictitious 'snail inch' unit to the real 'slug foot' (yes such a thing does appear to exist), which is then commented on further. Again arguably this could be coded as an extension but the phrase 'we are left with' suggested emphasis would be the better categorization.

3rd Category: In some cases memes found in the data are 'extensions' of the previous exchanges in that the content of the previous exchange is added to in a way that extends it into new terrain rather than simply add detail as in the emphasis category. The relation between them is, therefore, one of imperfect copying and variation creation which adds breadth rather than adding depth (emphasis).

Organizational examples (Project)

Meme (provided for context):

Do you think Company X might be approachable?

Meme:

Definitely or one of the bigger end users.

Following meme:

You want someone who can distribute it though don't you. Once you have a demonstrator and once we are sure we can do it and our IP position is robust then we want to get it to the market as quickly as we can and Company $X$ fits that bill very well I would have thought. 
Here, in the exchange the knowledge content is extended into new territory talks of the commercialization of this Intellectual Property. If it had only included the first phrase about asking about a distribution company, it could have be coded as an emphasis. 4th Category: This category is only found in the organizational data set. The exchange takes place in the internal case with all three memes being spoken one after the other by the Scientific Director.

Meme 1:

Yes I think it's important that as David says that some of our key people are being listened to and they have a chance to ... there is some enthusiasm out there to do something with.

Meme 2:

Obviously we have got to set some boundaries otherwise we will just spend every single day just talking about ideas and not doing anything but I think it will have an impact.

Meme 3:

To be honest I do not care if after the first couple it goes stale because in two of those meetings one idea could come out, one thing could come from one of those things.

In this exchange, the Scientific Director combines various memes from previous discussions. Specifically he combines:

Meme 1-the notion that ideas need to be fed into the investment process through innovation meetings, with the role of people's enthusiasm within that.

Meme 2-the notion that the workload is manageable, with his view that the people are competent enough to produce new ideas.

Meme 3-the role of the directors (specifically him) in not worrying how long the new innovation meetings last for, with the role of the project managers in producing the ideas.

In this case knowledge from previous memes is joined together to make it mean something different. This category involves a form of abstraction to a higher level.

5th Category: In some cases memes found in the data had substantial new dimensions that differentiated them from extensions. The test of whether an exchange could be classified as an extension or a 'new dimension' is that, if one takes the meme as a standalone, would it be obvious is was part of the previous discourse. Substantial doubts that it is not, result in the meme being classified as a new dimension. The relation between them is, therefore, one of highly imperfect copying and variation creation of an innovative kind.

\section{Control example (Gun policy)}

Meme:

I have the information everyone here needs to report this site as spam to the hosts. The sender was stupid enough to use his actual account to send it. Anyway, ajcongress-ne.org exchange under in some groups as psego@ usa.net. Anyway the addresses below are to report the spammer. Please keep reading to report the SITE hosted in the spam, guncontrol.homepage.com By the way, this spam was exchanged to HUNDREDs of USENET newsgroups, so make sure you mention that in your complaints. The host of the spam site: hostmaster@RAPIDSITE>NET, abuse@rapidsite.et, buse@nameservers.netAbuse@verio.net 
Following meme:

To me, the real value of the internet is that it can be used to promote the dissemination of ideas, a function necessary to maintain and improve a democracy, not to sell more GAP clothes and make dot.com investors get rich.

In this exchange a lot of variation creation happens in that the role of the Internet in promoting a democracy of ideas is processed into the Internet being used for commercial ends, moving the discussion on substantially from reporting spam and taking it into the realms of the freedom of information. Freedom of information dominated content from there on.

6th Category: In some exchanges memes are found that are 'misinterpretations' of the previous meme. In some exchanges the mis-interpretation is deliberate involving a play on words, in other cases this category of replication involves an unintended mistake. The relation between them is, therefore, one of highly imperfect copying and variation creation that is accidentally highly innovative.

\section{Control example (Mars)}

Examples of both deliberate and unintended misinterpretations are provided below. Meme:

$$
\begin{aligned}
& 1 \text { foot }=12 \text { inches } ; 1 \text { yard }=3 \mathrm{feet}=36 \mathrm{in} ; 1 \mathrm{chain}=22 \mathrm{yrd}=66 \mathrm{ft}=2376 \mathrm{in} ; \\
& 1 \text { furlong }=10 \mathrm{ch}=220 \mathrm{yds}=660 \mathrm{ft}=23760 \mathrm{in} ; 1 \mathrm{mile}=8 \mathrm{frlg}=1760 \mathrm{yrd}=5280 \\
& f t=190080 \mathrm{in} ; \text { Interesting system, really. }
\end{aligned}
$$

Or, like Mr. 'Four Weddings' would say: 'Excellent!'

Following meme:

Interesting propagation of a numerical input error :-); $66 \mathrm{ft}=786 \mathrm{in}$, etc. .

Note- 'etc' is actually what was written and is not an editorial abbreviation. In this case an intended play on words is used to create a misinterpretation of the word 'interesting' to reveal a factual mistake (66' actually equals $\left.792^{\prime \prime}\right)$. An example of an unintended misinterpretation is given below:

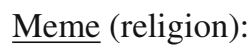

You're a Winnipegger!?!? I am sooooooooo embarrassed ...

People .... This nut is NOT representative of the people you'll find in the Peg.

This meme has no place in this chat room and is in fact the result of someone replying to the wrong chat room yet the lineage continues for five exchanges.

7th Category: Lastly there is the category of 'no retention' of the meme, it never being replicated in the whole population. Irrespective of what other category it fell it to, was it variation that was never repeated again? The knowledge is therefore lost from the data-set and hence the knowledge pool the discourse represents. This is a special case of variation creation in that it is not a matter of degree of copying but a matter of an absence of copying. It is the ultimate in the creation of variation on the one hand but one the other it is destroyed by not being retained.

\subsection{Inter-coder reliability}

As the examples of memes show, it is not easy to determine when enough words have been said for the sequence of words to have unique so-called 'stand-alone 
meaning', taking into consideration what might reasonably be considered as meaningful in the context under study. For example, managerial jargon such as 'Gate 2' could be considered as a meme in itself (especially outside of the context of New Product Development). The emoticon ':)' outside of those familiar with such new ICT based meaning (which included a reviewer) has no meaning unless perhaps represented as :). Equally for some, amounts of money, such as ' $2 \mathrm{~K}$ ', are socially constructed terms and in this case less meaningful outside the British culture in which these data were collected.

Given the various possibilities of interpretive ambiguity and possible wishful thinking, a second coder independently coded a significant amount of the data. Replicative coding of both raw data into memes and memes into categories of variation took place to assess whether the coding was reliable and to determine what rules made it more reliable. Again all second coding is available in the form of an audit trail from transcripts to meme identification to categorization.

The second coder was familiar with the context of innovation because she had spent much time taking the minutes of such meetings within similar companies in the UK. Data to be second coded were chosen at random from the 3 cases. In total, 208 data points made up of 104 memes and 104 categorizations were coded. Practice by both the first and second coder and coder inter-reliability analysis reduced interpretation discrepancies from $48 \%$ to $5 \%$ of the data. Coder discussions included either the generation of a rule both coders understood and produced no discrepancy when applied, or discussion that resulted in the choice of the coding opted for by one or the other coder, or a discrepancy remained.

Methodological problems discerned during second coding included defining better what is to be counted as content. For example a 'yes' statement of agreement carries the content of the previous statement and is a stand-alone meme. Another example involves considering all content including humor to be memetic. Conflicting interpretations of the content in this context reveals how important it is to find coders knowledgeable and used to the chosen setting for data collection. Implicit meaning initially was not coded by the second reader. Working at different levels of detail initially caused discrepancies in number of memes found. Discrepancies in categorization were also discovered but were easy to resolve.

Interestingly, geneticists are still not sure where one gene ends and another begins and hence how many genes there are in the human genome, although they are ever more certain that loci of high variation create the most useful genetic insights (International HapMap Consortium 2005). Indeed, it is argued that it is the variation between genes that counts more than arriving at a definitive number (Gibbs 2005). Research on genetic variation is nearing completion (Goldstein and Cavalleri 2005). This recent emphasis in genetics gives credence to methods reported for analyzing memes, where identification of memes is a means to an end (insights into variation creation), rather than insights in and of themselves.

To conclude, Shepherd's previous experience working in genetics served as an inspiration and a source of ideas for the methods described here; they augmented established sociological techniques such as content analysis and grounded theory. Even so, theorizing from process data is messy and involves: 
- Finding a balance between concluding that everything is complex versus generating normative laws;

- Moving between theory and data at the same time as sense making; and

- Features uncodifiable moments of inspiration (Langley 1999).

This research is no exception.

\section{Results}

We now analyze the data to see whether it produced any meme variation findings that could be considered coherent, recognizing that the process for accurately identifying memetic variation patterns is nascent. We do not take coherence, per se, as a guarantee that memes have been accurately identified. Instead, coherence here is best interpreted as suggesting that further investigations of the same kind are worth pursuing. Coherence in this study is defined to occur if results are in line with predictions, such as: Do the management meetings show levels of variation aligned with the expectation of innovation? Does the more subjective case of 'Why fear God?' show more variation than the scientifically objective Mars case, as it should? Does the spam within the Gun Policy case reduce variation? Do the Internet cases show more variation than the discussions in the Portfolio Committee, as expected?

Results are presented in ways that highlight differences and similarities between the cases. Fig. 1 presents the data in a way that places the categories in order of how much variation they add, per setting and per case. Thus, the data are provided in the order of repeat, emphasis, extension, combination, new dimension, misinterpretation, and no retention. This graph is designed to reveal whether there are any similarities and differences among and within settings as to how much variation is added. Fig. 2 is organized to show the most-to-least popular categories so as to reveal whether there is any similarity within and between the settings as to which category is more or less present. This is necessary because different mixtures of categories could still add the same amount of variation.

Our results indicate what we expected, given our rationale for choosing these settings and these particular cases in the first place-as explained in the Method section. First, our graphs reveal that every case has a unique amount of each category. As in genetics, each case has a unique memetic fingerprint. So, when viewed at a sufficiently micro level, organizing is memetically unique. This said, comparisons within and between settings could still show more or less similarity among fingerprints.

Second, taking a broad view, Fig. 1 shows that, on average, the cases in the management setting exhibit smaller amounts of variation production than the Internet setting. The former have distributions that are skewed to the left-hand side and hence towards categories that do not add much if any variation, such as repeat and emphasis. The control settings have distributions skewed more to the right and hence towards new dimension, misinterpretation, and no retention.

Third, looking at the cases within the settings, Project exhibits the lowest amount of variation creation, with a very strong showing in the emphasis category and few new dimensions. Off Agenda, in comparison, has a greater number of repeats but fewer emphasis memes and more new dimensions. Internal has fewer emphasis memes but 


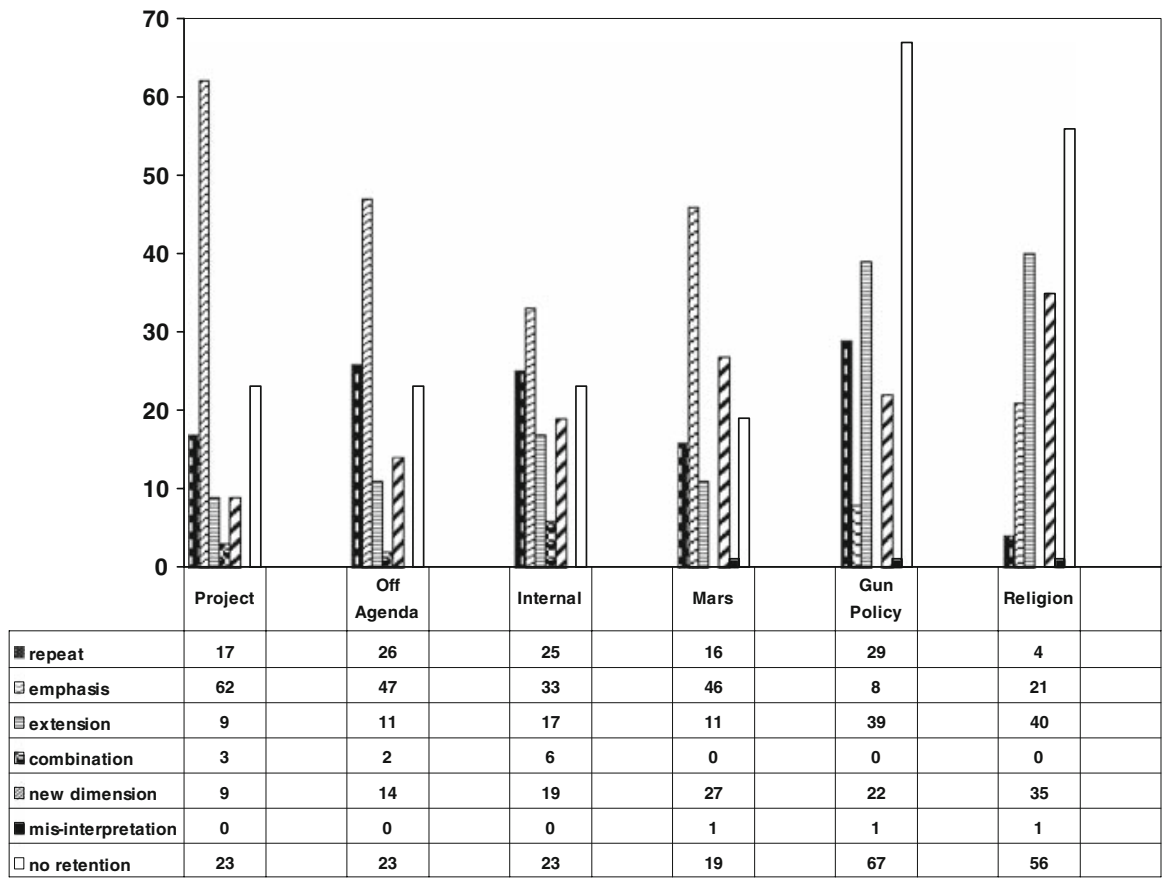

Fig. 1 Percentage of each category in order of how much variation is added

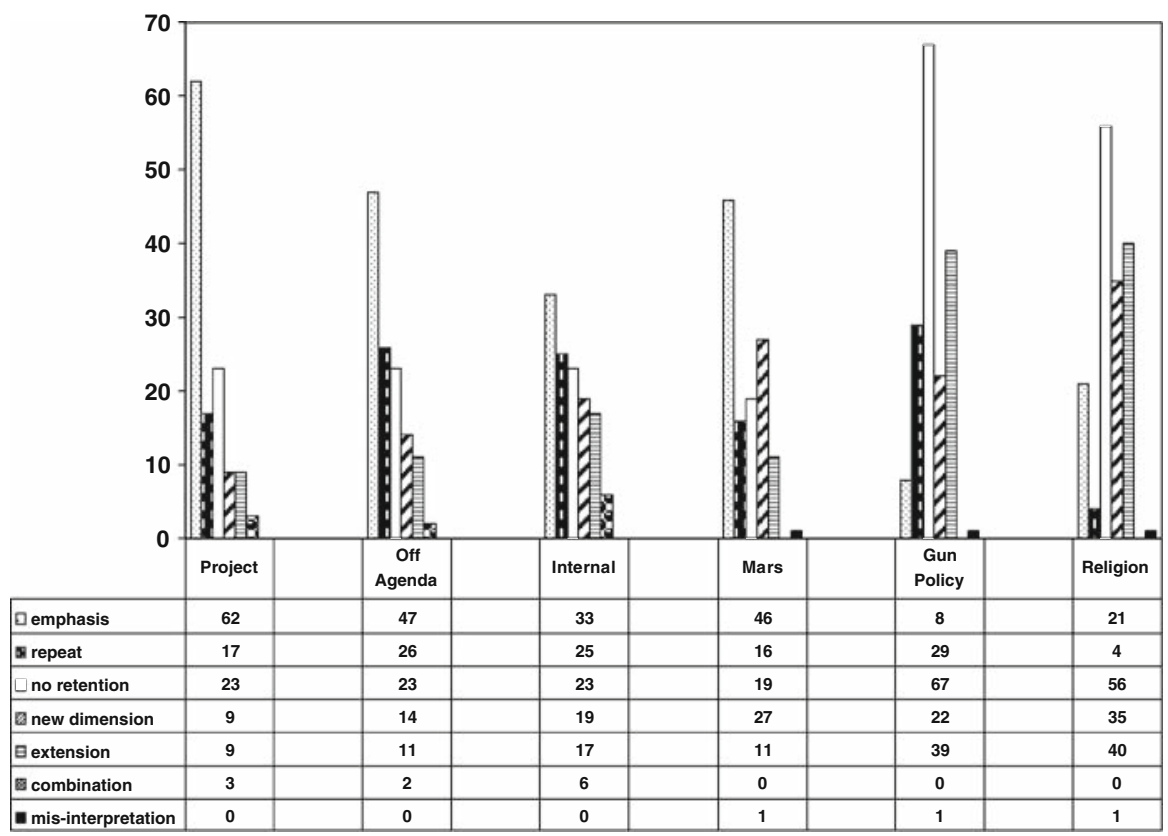

Fig. 2 Percentage of each category by most-to-least popular in commercial test setting 
still a decent number of repeats, but again an even higher number of new dimension memes. This is as expected; Project should contain less variation than innovationdriven Internal. Equally, Off Agenda ought to have more variation than Project but less than Internal, as it is not a conversation directed towards a goal as is Project; but it does end up being somewhat comparable since a project is the major item discussed.

Mars looks most like the management settings, having less variation added than the Gun Policy and Religion cases but as much, if not more, than any management setting. This is as predicted; Mars is a largely rational conversation mostly between a small number of scientists about whether something is 'right' or 'wrong'. Above all, the amount of the category emphasis is far more typical of the management setting than the remaining two cases of the control setting. Gun Policy is high added variation especially in the no retention category; but overall, however, the amount of variation added is countered by a large number of repeats. Again this is as predicted, given this chat room contains a lot of spam but the discussion is amongst many people and is full of many different views. Religion contains the most overall variation, with more new dimensions not countered by a large component of repeats. Again this is also as predicted; the people are numerous and diverse, there is no spam and the topic is subjective.

The potential insight here is that the nature of the management setting - a small number of people all with very similar (scientific) backgrounds, who have worked together for a long time, meeting face to face-create less new knowledge than many more people meeting for the first time virtually, especially if they are working within Netiquette and are talking about something in a less than factual, scientific way. Banning spam or adhering to brainstorming rules increases variation production. Virtuality, as seen in the cohesive Mars case, does not, per se, increase variety creation. The foregoing differences demonstrate that memetic method appears to be accurate enough to pick up more subtle (within case) differences.

Figure 2 arranges the same data into a format of most prevalent category first, second most prevalent second etc, using the management setting as the starting point, thereby allowing it to be viewed from a different angle. In the management setting, the most popular category in all three cases is emphasis and the second most popular category in all three cases is repeat (except in Project where this category is third). The third most popular is no retention (except in Project where it is second). In all cases, the fourth most popular is new dimension, the fifth extension and the sixth most popular is combination. Misinterpretation is the least popular category, indeed none occur in any management cases, of which more later. In the Internet setting emphasis is most popular in Mars, fourth in Religion and fourth in Gun Policy. Repeat is third most popular in Mars, fourth in Religion and third in Gun Policy. No retention is third in Mars, first in religion, and first in Gun Policy. New dimension is second in Mars, third in Religion and fourth in Gun Policy. Extension is fourth in Mars, second in Religion and second in Gun Policy. Combination is absent in all three and misinterpretation is present in all three in equal amounts.

Figure 2 actually emphasizes findings in Fig. 1. Thus, the case, Mars, is similar to the management setting, whereas Gun Policy and Religion are more similar to each other. Gun Policy's variation pattern appears different because of the high number of repeats, whereas Religion is a more 'pure' high variation pattern. 
Table 4 Categories of variation

\begin{tabular}{|c|c|c|c|c|}
\hline Category & Sub-category & Nature of copying & Variation & $\begin{array}{l}\text { Management }(\mathrm{M}) \\
\text { Internet Control }(\mathrm{C}) \text { ? }\end{array}$ \\
\hline Repeat & $\begin{array}{l}\text { Knowledge } \\
\text { repeated }\end{array}$ & $\begin{array}{l}\text { Near perfect or } \\
\text { perfect sharing }\end{array}$ & None & $M \& C$ \\
\hline Emphasis & Added detail & $\begin{array}{l}\text { Medium, } \\
\text { imperfect } \\
\text { sharing }\end{array}$ & Moderate & M \& C \\
\hline Extension & $\begin{array}{l}\text { Additional } \\
\text { knowledge }\end{array}$ & $\begin{array}{l}\text { Medium, } \\
\text { imperfect } \\
\text { sharing }\end{array}$ & Moderate & $M \& C$ \\
\hline Combination & $\begin{array}{l}\text { Two pieces of } \\
\text { knowledge are } \\
\text { connected in } \\
\text { some way }\end{array}$ & $\begin{array}{l}\text { Both imperfect \& } \\
\text { perfect at the } \\
\text { same time }\end{array}$ & Moderate-to-High & M \\
\hline New dimension & $\begin{array}{l}\text { Content is related } \\
\text { to previous but } \\
\text { is all new } \\
\text { content }\end{array}$ & $\begin{array}{l}\text { Low, imperfect } \\
\text { sharing medium } \\
\text { change }\end{array}$ & High & $M \& C$ \\
\hline Mis-interpretation & $\begin{array}{l}\text { New content does } \\
\text { not resemble } \\
\text { previous content }\end{array}$ & $\begin{array}{l}\text { Very low, } \\
\text { imperfect } \\
\text { sharing }\end{array}$ & $\begin{array}{l}\text { Very high } \\
\text { /disjointed }\end{array}$ & $\mathrm{C}$ \\
\hline No retention & $\begin{array}{l}\text { No replication of } \\
\text { knowledge }\end{array}$ & Zero sharing & Variation reduced & $M \& C$ \\
\hline
\end{tabular}

Fourth, looking at which categories of memetic variation (akin to genetic mutation or recombination) are found in each setting, differences are found between them. Table 4 summarizes the detail of categorizations of how memes vary, adding in what settings the category is found. Categories repeat, emphasis, extension, new dimension and no retention are found in both settings. Misinterpretation is not found in the management setting whereas combination is not found in the Internet setting. Combination, in the sense of taking a so-called helicopter view, appears to be (more of) a managerial way of adding variation and is arguably a rare strategic skill. As regards misinterpretations, groups of people well versed in exchanges among themselves rarely make the 'mistake' of misinterpretation (management setting) but arguably miss out on highly innovative variation production as a consequence.

This management team, a long established one, appears unable to adapt their variation-creation patterns effectively to different tasks. Whether they are being innovative (Internal) or exchanging knowledge to come to an agreement (Project) or having an Off Agenda conversation, they add similar amounts of variation in a very similar way. They are trapped in a type of memetic evolution which is characteristic of scientists solving rational problems in a stable physical world (remember, also, that they were a government organization before going private). As such, their memetic evolution is not as varied as it could be; it is clearly less than that of the control setting and the type of setting they are thinking of migrating to. Virtuality might help, but probably not because virtuality per se (albeit this might be responsible for the misinterpretation category), but because virtuality allows a greater number of people-usually with more diversity - to contribute to the coevolutionary process. 


\section{Conclusion}

Our research makes several significant, novel contributions:

1. It develops a method to empirically identify and evaluate memes and memetic variation.

2. Using a way of accessing variation creation, it shows quantitative and qualitative differences in variation creation between and within two different settings: Project Management and Internet.

3. It applies this method in a fashion that starts the process of assessing the reliability of the method by comparing two settings and three cases within each of these contrasting settings:

a. As predicted, our memetic analysis shows that - in a firm thinking it was not behaving very innovatively — the key 'Portfolio Management Committee' is, in fact, not showing much memetic variation; and

b. Our (high variation) control settings of Internet chat rooms, indeed, show high memetic variation.

We propose that, should our work be replicated, such insights have implications in terms of allowing managers to see quickly whether they have adaptive organizational capability (Burgelman 2002). The ability to assess adaptive organizational capability early in the variation-selection-retention process has to be advantageous in times where the environment changes ever faster.

Inevitably, limitations prevail in research such as ours. We aim at empirically identifying memes and the way in which they vary in organizations. It is a minimal test of organizational variation; the method needs to be repeated in other contexts to further develop and test its validity. Currently, creating and working with memetic data-sets is time consuming, messy, subjective, and fraught with theoretical controversy (Aunger 2000). A complimentary research strategy is to look for entrenched internal selection-retention patterns in all data over short time periods that might stop variation from thriving. Others might interpret the work of Weeks and Galunic, or Dawkins, or Dennett in very different ways.

Irrespective of these limitations, if the field of evolutionary organizational research is to move forward, empirical memetic work needs to be conducted so as to combine studies of coevolving micro and macro evolutionary dynamics into a comprehensive, unified field, as has already happened in biology with the reconciliation of the ultraDarwinist 'selfish gene' school (Dawkins 1976; Maynard Smith 1993) with that of the paleontologists (Stanley 1979; Eldredge 1995; Gould 2002). In the sense that 'firms have us' as much as 'we have them' (Weeks and Galunic 2003), our paper shows how every exchange between managers creates (or does not create) variation that cumulatively makes up the cultural milieu of organizing. There has to be a link between the very micro and macro outcomes and that link as to be worth investigating and must be investigated empirically.

Compared to macro evolutionary research, micro evolutionary-memeticorganizational research has not seen anywhere near commensurate empirical progress. Yet, as in genetics, it holds great theoretical promise, as it does not assume intrinsic 
efficiency (Weeks and Galunic 2003) and considers the organization to coevolve with its environment (Lewin and Volberda 2003). Our research makes use of microstate adaptations over time (McKelvey 1997) interpreted in the form of memes that vary to different degrees in different ways and are selectively retained (Shepherd 2002).

How memes vary on an everyday basis is not controllable, both because so many memes vary even in short periods of time and because we cannot control how we interpret another person's meaning and hence what variation is created. Previous empirical work looks at how selection-retention forces can be more or less aligned, and with what consequent effects on performance. Selection can, nevertheless, only work on variation and so, if there is insufficient variation, selection will be ineffective however it operates (Kauffman 1993). Our research, therefore, looks at whether a better understanding of variation-creation dynamics can be created to make the process more manageable.

Even though Dawkins invented 'memes' in 1976 as a parallel concept to genes, and even though memetic theory has since developed in the social sciences, the 'selfish meme' type of move to micro evolutionary organizational analysis has not occurred in organization theory. Consequently, the kind of empiricism that combines micro/macro evolutionary analysis into a single comprehensive perspective is not much evident in organizational evolutionary research (McKelvey 1997; Lewin and Volberda 2003) or generally in organizational research (Hitt et al. 2007). Ours is a tentative first empirical move in organizational research toward the micro/macro resolution we see in biology.

Acknowledgements Jill would like to thank her PhD supervisor Gerry Johnson, her co-author Bill McKelvey and the second coder Andrea Moulding for their long-standing and patient support of her research. Both authors thank the three anonymous reviewers for their detailed and valuable feedback.

\section{References}

Aldrich, H. E. (1979). Organizations and environments. Englewood Cliffs, NJ: Prentice-Hall.

Aldrich, H. E. (1999). Organizations evolving. London: Sage.

Aldrich, H. E., \& Ruef, M. (2006). Organizations evolving (2nd ed.). London: Sage.

Ashby, W. R., (1956). An introduction to Cybernetics. London: Chapman \& Hall.

Augier, M., \& Winter, S. G. (2005). Why is management an evolutionary science? An interview with Sidney G. Winter. Journal of Management Inquiry, 14, 344-354.

Aunger, R. (2000). Darwinizing culture. Oxford, UK: Oxford University Press.

Bjelland, O. M., \& Wood, R. C. (2008). An inside view of IBM's innovation jam. MIT Sloan Management Review, 50, 32-40.

Blackmore, S. (1998). Imitation and the definition of a meme. Journal of Memetics_Evolutionary Models of Information Transmission, 2, 1-10. http://jom-emit.cfpm.org/1998/vol2/blackmore_s. html. Accessed 25 May 2009.

Blackmore, S. (2000). The meme's eye view. In R. Aunger (Ed.), Darwinizing culture (pp. 25-42). Oxford, UK: Oxford University Press.

Blute, M. (2005). Memetics and evolutionary social science. Journal of Memetics—Evolutionary Models of Information Transmission, 9, 1-4. http://cfpm.org/jom-emit/2003/vol7/blute_m.html. Accessed 25 May 2009.

Boisot, M. (1998). Knowledge assets. New York: Oxford University Press.

Boisot, M., \& Li, Y. (2006). Organizational versus market knowledge: From concrete embodiment to abstract representation. Journal of Bioeconomics, 8, 219-251. 
Brown, S. L., \& Eisenhardt, K. M. (1997). The art of continuous change: Linking complexity theory and time-based evolution in relentlessly shifting organizations. Administrative Science Quarterly, 42, 134.

Burgelman, R. A. (1983). Corporate entrepreneurship and strategic management: Insights from a process study. Management Science, 29, 1349-1364.

Burgelman, R. A. (1991). Intraorganizational ecology of strategy making and organizational adaptation: Theory and field research. Organization Science, 2, 239-262.

Burgelman, R. A. (2002). Strategy is destiny. New York: Free Press.

Burke, D. S. (1997). Recombination of HIV: An important viral evolutionary strategy. Emerging Infectious Diseases, 3. http://www.cdc.gov/ncidod/eid/vol3no3/burke.htm. Accessed 25 May 2009.

Burt, R. S. (2005). Social brokerage and closure. Oxford, UK: Oxford University Press.

Business Week. (2006a). Speed demons: How smart companies are creating new products—and whole new businesses_almost overnight. March 27. http://www.businessweek.com/magazine/content/06_13/ b3977001.htm. Accessed 25 May 2009.

Business Week. (2006b). The world's most innovative companies. April 24. http://www.businessweek. com/magazine/content/06_17/b3981401.htm. Accessed 25 May 2009.

Campbell, D. T. (1960). Blind variation and selective retention in creative thought as in other knowledge processes. Psychological Review, 67, 380-400.

Campbell, D. T., \& Stanley, J. C. (1963). Experimental and quasi-experimental designs for research on teaching. In N. L. Cage (Ed.), Handbook of research on teaching (pp. 171-246). Chicago, IL: Rand McNally.

Dawkins, R. (1976). The selfish gene. Oxford, UK: Oxford University Press.

Dawkins, R. (1982). Organisms, groups and memes: Replicators or vehicles. Oxford, UK: Oxford University Press.

Dennett, D. C. (2006). From typo to thinko: When evolution graduated to semantic norms. In S. C. Levinson \& P. Jaisson (Eds.), Evolution and culture (pp. 133-145). Cambridge, MA: Bradford/MIT Press.

Depew, D. J., \& Weber, B. H. (1995). Systems dynamics and the genealogy of natural selection. Cambridge, MA: MIT Press.

Durham, W. H. (1991). Coevolution: Genes, culture, and human diversity. Stanford, CA: Stanford University Press.

Eldredge, N. (1995). Reinventing Darwin. New York: Wiley.

Fisher, R. A. (1930). The genetical theory of natural selection. Oxford, UK: Clarendon Press.

Fox, K, E., \& Harel, D. (2007). Beyond the gene. PLoS ONE, 2(11), e1231. doi:10.1371/journal. pone.0001231. http://www.plosone.org/article/info\%3Adoi\%2F10.1371\%2Fjournal.pone.0001231. Accessed 25 May 2009.

Friedman, M. (Ed.). (1953). Methodology of positive economics. In Essays in positive economics (pp. 3-43). Chicago, IL: University of Chicago Press.

Gabora, L. (1997). The origin and evolution of culture and creativity. Journal of Memetics_Evolutionary Models of Information Transmission, 1, 1-14. http://cfpm.org/jom-emit/1997/vol1/gabora_l.html. Accessed 25 May 2009.

Gatherer, D. (1998). Why the 'thought contagion' metaphor is retarding the progress of memetics. Journal of Memetics-Evolutionary Models of Information Transmission, 2, 1-22. http://cfpm.org/ jom-emit/1998/vol2/gatherer_d.html. Accessed 25 May 2009.

Gibbs, R. (2005). Deeper into the genome. Nature, 437, 1233-1234.

Glaser, B. G. (1992). Emergence versus forcing: The basics of grounded theory analysis. Mill Valley, CA: Sociology Press.

Goldstein, D. B., \& Cavalleri, G. L. (2005). Genomics: Understanding human diversity. Nature, 437, 12411242.

Gould, S. J. (1992). The confusion over evolution. The New York Review of Books, 39(19), 47-54.

Gould, S. J. (2002). The structure of evolutionary theory. Cambridge, MA: Belknap/Harvard University Press.

Heyes, C. M., \& Plotkin, H. C. (1989). Replicators and interactors in cultural evolution. In M. Ruse (Ed.), What the philosophy of biology is: Essays dedicated to David Hull (pp. 139162). Dordrecht: Kluwer. 
Hinds, D. A., Stuve, L. L., Nilsen, G. B., Halperin, E., Eskin, E., Ballinger, D. G., Frazer, K. A., \& Cox, D. R. (2005). Whole-genome patterns of common DNA variation in three human populations. Science, 307, 1072-1079.

Hitt, M. A., Beamish, P. W., Jackson, S. E., \& Mathieu, J. E. (2007). Building theoretical and empirical bridges across levels: Multi-level research in management. Academy of Management Review, 50, 1385-1399.

International HapMap Consortium. (2005). A haplotype map of the human genome. Nature, 437, 12991320.

Janis, I. (1972). Groupthink (2nd ed.). Boston, MA: Houghton Mifflin.

Kauffman, S. A. (1993). The origins of order. New York: Oxford University Press.

Kogut, B., \& Zander, U. (1992). Knowledge of the firm, combinative capabilities, and the replication of technology. Organization Science, 3, 383-397.

Krippendorff, K. (1980). Content analysis: An introduction to its methodology. Newbury Park, CA: Sage.

Langley, A. (1999). Strategies for theorizing from process data. Academy of Management Review, 24, 691710.

Lewin, A. Y., \& Volberda, H. Y. (2003). Beyond the selection-adaptation debate. In H. Tsoukas \& C. Knudsen (Eds.), The Oxford handbook of organization theory (pp. 569-595). Oxford, UK: Oxford University Press.

Lewontin, R. C. (1978). Adaptation. Scientific American, 239, 212-230.

Lissack, M. R. (2004). The redefinition of memes: Ascribing meaning to an empty cliché. Journal of Memetics-Evolutionary Models of Information Transmission, 8, 1-13. http://cfpm.org/jom-emit/ 2004/vol8/lissack_mr.html. Accessed 25 May 2009.

Lord, A., \& Price, I. (2001). Reconstruction of organisational phylogeny from memetic similarity analysis: Proof of feasibility. Journal of Memetics-Evolutionary Models of Information Transmission, 5, 1-9. http://jom-emit.cfpm.org/2001/vol5/lord_a\&price_i.html. Accessed 25 May 2009.

Marra, M., Jones, S. J., Astell, C. R., Holt, R. A., \& Brooks-Wilson, A. (2003). The genome sequence of SARS-associated coronovirus. Science, 300, 5624-5699.

Martzen, M. R., McCraith, S. M., Spinelli, S. L., Torres, F. M., Stanley, F., Grayhack, E. J., \& Phizicky, E. M. (1999). A biochemical genomist approach for identifying genes by the activity of their products. Science, 286(5442), 1153-1155.

Maynard Smith, J. (1993). The theory of evolution (3rd ed.). Cambridge, UK: Cambridge University Press.

McKelvey, B. (1982). Organizational systematics. Berkeley, CA: University of California Press.

McKelvey, B. (1997). Quasi-natural organization science. Organization Science, 8, 351-380.

Mintzberg, H., \& McHugh, A. (1985). Strategy formation in an adhocracy. Administrative Science Quarterly, 30, 160-197.

Myers, S., Bottolo, L., Freeman, C., McVean, G., \& Donnelly, P. (2005). A fine-scale map of recombination rates and hotspots across the human genome. Science, 310(5746), 321-324.

Nelson, R. R., \& Winter, S. G. (1982). An evolutionary theory of economic change. Cambridge, MA: Harvard University Press.

Rose, N. (1998). Controversies in meme theory. Journal of Memetics-Evolutionary Models of Information Transmission, 2, 1-10. http://jom-emit.cfpm.org/1998/vol2/Rose_n.html. Accessed 25 May 2009.

Rosness, R. (2004). 'I think I understand what you mean': Negotiating intersubjective understanding. In A. Carlsen, R. Klev, \& G. Kroghvon (Eds.), Living knowledge (pp. 99-114). Basingstoke, Hampshire: Palgrave Macmillan.

Sampler, J. L. (1998). Redefining industry structure for the information age. Strategic Management Journal, 19, 343-355.

Shepherd, J. (2002). An evolutionary (memetic) perspective on how and why does knowledge emerge? PhD Dissertation, University of Strathclyde, Glasgow, Scotland.

Speel, H.-C. (1999). Memetics: On a conceptual framework for cultural evolution. In F. Heylighen, J. Bollen, \& A. Riegler (Eds.), The evolution of complexity (pp. 229-254). Norwell, MA: Kluwer.

Spencer, H. (1897). The principles of sociology. New York: D. Appleton \& Co.

Stanley, S. M. (1979). Macroevolution, pattern and process. San Francisco, CA: W. H. Freeman.

Sterelny, K. (2001). Dawkins versus Gould. Cambridge, UK: Icon Books. 
Tsoukas, H., \& Mylonopoulos, N. (2004). What does it mean to view organizations as knowledge systems?. In H. Tsoukas \& N. Mylonopoulos (Eds.), Organizations as knowledge systems (pp. 126). Hampshire, UK: Palgrave Macmillan, Basingstoke.

Voelpel, S. C., Leibold, M., \& Streb, C. K. (2005). The innovation meme: Managing innovation replicators for organizational fitness. Journal of Change Management, 5, 57-69.

Vos, E., \& Kelleher, B. (2001). Mergers and takeovers: A memetic approach. Journal of MemeticsEvolutionary Models of Information Transmission, 5, 1-12. http://jom-emit.cfpm.org/2001/vol5/ vos_e\&kelleher_b.html. Accessed 25 May 2009.

Watson, J., \& Crick, F. (1953). Molecular structure of nucleic acids: A structure for deoxyribose nucleic acid. Nature, 171(4356), 737-738.

Weeks, J. R., \& Galunic, C. (2003). A theory of the cultural evolution of the firm. Organization Studies, 24, 1283-1304.

Williamson, O. E. (1975). The economic institutions of capitalism. New York: Free Press. 